towards the close of 1935, and seven years before, about the same time of the year, the first record of the species in African waters was made when about a hundred came ashore at Kommetjie, some sixteen miles south of Cape Town.

\section{Canadian Reindeer Herd}

THE introduction of a herd of reindeer to Canada as an addition to the food resources of the far north has met with success. Notwithstanding the severity of the winter, the herd on its winter range east of the delta of Mackenzie River in the Northwest Territories is reported by the Office of the High Commissioner to be in good condition, and to number about 3,000. Surplus males to the number of 200 were slaughtered during the autumn and the carcasses used for food, while the hides were used for moccasins, mittens and other items of wearing apparel. The herd, accompanied by its herders, undertakes a regular north and south migration, moving northward along the arctic coast early in April and southward again in late autumn, grazing by the way over the hills and valleys of its reserve of 6,600 square miles.

\section{American Research Grants}

PART 3 of volume 76 of the Proceedings of the American Philosophical Society contains the report for the first three years of its operation of the Committee on Research established by the Society. The Committee set apart 20,000 dollars in 1933, 45,000 dollars in 1934, 60,000 dollars in 1935, and 50,000 dollars in 1936. Ninety-eight grants have been made of the average value of 1,500 dollars: sixteen in zoology, fourteen each in physies and botany, ten in astronomy, nine each in geology and physiology, six in chemistry, five in archæology and smaller numbers in other subjects. These grants are more generous than those made by the National Research Council but are less than those made by some of the great foundations. The Committee proposes to hold each year an autumn meeting at which the reports of grantees as to the progress of their researches will be read. The Committee would welcome suggestions for improving its methods of aiding research.

\section{Research Grant Board, South Africa}

The recently issued report of the Research Grant Board, Union of South Africa, covers the period 1918-35. The Board was established in October 1918 as a result of a recommendation of the Advisory Board of Industry and Science, which had been formed earlier that year from an amalgamation of the Industries Advisory Board and "a Scientific and Technical Committee". It was at first proposed that the Research Grant Board should be attached to the Department of Agriculture, but after forming a subcommittee of the Advisory Board until the dissolution of the latter in 1923, it was attached to the Department of Mines and Industries until 1933, when it was transferred to the newly-formed Department of Commerce and Industries. While attached to one Department, the Board is regarded as serving all branches of Government, recognition being given to this relationship by the presence on the Board of assessor members from other Departments. Initially, the Board's activities were confined to the encouragement of research in universities and museums, but its scope was speedily extended to embrace every branch of knowledge and to include the whole country irrespective of institutions.

ONE of the most important functions of the Board is the administration of Government grants in aid of research as well as research scholarships. It has also undertaken similar duties on behalf of the Carnegie Corporation of New York, which has allocated generous funds for research in South Africa. As at first constituted, the Board consisted of representatives of science and industry, together with the assessor members from Government Departments. When its scope was enlarged, members were added to represent other than scientific subjects. While ordinary members of the Board have been chosen with an eye to representation of all the interests concerned, they are regarded as serving wholly in their individual capacity and responsible only to the Minister. The success and efficiency of the Board are attributed largely to this arrangement and to the spirit of unity it engenders, and also to the excellence of its personnel and the unstinted manner in which they have given of their best to the work.

\section{Carnegie Institution of $W_{\text {ashington }}$}

THe report of the president of the Carnegie Institution of Washington for the year ending October 31, 1935, refers to developments in methods and organization of research in the Institution, particularly in the support of larger projects and the co-operation of fair-sized groups of individuals, as in the Geophysical Laboratory, Mount Wilson Observatory and the Department of Genetics. Its present organization is adapted not only to the advance of knowledge in new interlocking or overlapping areas of research, but also to bring back to each of the groups engaged upon special problems a wide range of materials otherwise not readily secured. Reference is made in the report to the progress of seismological research and of the investigations on terrestrial magnetism. Astronomical work has included study of the nova in Hercules, of stellar atmospheres, extra-galactic nebulæ, measurement of the velocity of light and observations of sunspot activity. Assistance has been given to research on cosmic rays and on the hydrodynamics of the atmosphere and major climatic variations. Numerous investigations have been carried out by the Department of Plant Biology, including the study of the influence of climatic environment on the life and development of living organisms, and by the Division of Animal Biology which includes the Department of Embryology, the Nutrition Laboratory and the Department of Genetics. Of outstanding interest are the activities of the Division of Historical Research, established in 1929, which has provided the opportunity to study history as science, art, culture, sociology and government in all phases with the application of scientific principles to the collection of materials and to the interpretation of the data 
acquired. The rapprochement of scientific and cultural or human interests in this way is an outstanding achievement of the Institution.

\section{Conference on College Hygiene}

THE second National Conference on College Hygiene of the United States will be held in Washington, D.C., on December 28-31 under the joint sponsorship of the American Student Association, the National Health Council and the President's Committee of Fifteen on College Hygiene. There will be no formal programme, but the work will be divided into five sections devoted respectively to health service, health teaching, organization and correlation, special problems and relationship of college hygiene to training and secondary education. Dr. Livingston Farrand, president of Cornell University, from whom further information can be obtained, is chairman of the Conference.

\section{Indian Science Abstracts}

THE National Institute of Sciences of India has recently issued the first number of Indian Science Abstracts, an annotated bibliography of science in India, including abstracts of all papers published in India or abroad on work done in India or based on Indian material. The first part includes abstracts arranged tentatively under nine headings. To ensure continuity under each heading and to facilitate reference, the abstracts dealing with each science have been given a separate pagination with the serial number of the heading preceding it. The abstracts in each section are arranged alphabetically and numbered serially. The general editor is Dr. Baini Prashad, who is assisted by nine associate editors for different subjects.

\section{Announcements}

Dr. Hans von Euler-Chelpin, professor of organic chemistry at Stockholm, has been elected an honorary member of the Association of German Chemists ; the Justus Liebig Medal of the Association has been awarded to Dr. Gustav Hittig, professor of inorganic and analytical chemistry at the German Technical University at Prague; and the Carl Duisberg Memorial Prize to Dr. Rudolf Tschesche, of Göttingen.

A PRIzE of 1,000 dollars is offered by the Williams and Wilkins Publishing Company for the best work on a science subject presented before July 1, 1937 . The work must be in English and the desired length is 100,000 words. Further information can be obtained from the Company, Mt. Royal and Guilford Avenue, Baltimore, Maryland.

DuRING the forthcoming winter, Mr. H. V. Garner, the guide demonstrator of the Rothamsted Experimental Station, Harpenden, Herts, and other members of the staff, are prepared to give a few lectures to chambers of agriculture and horticulture, farmers' clubs, farm workers' associations, agricultural societies, etc., on the Rothamsted experiments. Among the subjects offered are: manures, fertilizers, soil micro-organisms (Bacteria, Protozoa, etc.), agricul- tural botany, agricultural chemistry, soil physies, entomology, and plant pathology. Further information can be obtained from the Secretary, Rothamsted Experimental Station, Harpenden, Herts.

Mr. W. J. HALL, of Walsall, who was formerly with the Wool Industries Research Association at Leeds, and later with British Celanese Ltd., has been appointed technical editor of the Journal of the Textile Institute.

Messrs. Adlard AND Son, LTd., presented to members of the British Association at Blackpool a handy pocket diary, the main part of which consists of a calendar (September 1936-July 1937) of the meetings of scientific societies. Copies of the little book can be obtained from Messrs. Adlard at 21 Hart Street, London, W.C.1, price $6 d$.

Applications are invited for the following appoint. ments, on or before the dates mentioned :

A principal of Llanelly New Mining and Technical Institute - The Clerk of the Education Committee, County Education Offices, Carmarthen (September 28).

An assistant lecturer in mathematics in the Huddersfield Technical College-The Director of Education, Education Offices, Peel Street, Huddersfield (September 30).

An assistant lecturer in metallurgy in University College, Swansea-The Registrar (September 30).

An assistant (Grade III) in the Air Ministry Scientific Pool, for service at the Royal Aircraft Establishment, South Farnborough-Chief Superintendent, Royal Aircraft Establishment, quoting Ref. A.248 (October 2).

An assistant keeper on the higher technical staff of the Science Divisions of the Science Museum-The Director, Science Museum, South Kensington, London, S.W.7 (October 12).

An assistant county dairy instructor for Hampshire-County Agricultural Organizer, The Castle, Winchester (October 12).

A chemist in the Aeronautical Inspection Directorate Test House, Kidbrooke (non-metallic materials section, oils and petrols sub-section)-Secretary, Air Ministry (S.2.d.), Adastral House, Kingsway, W.C.2 (October 24).

A director of the Kanematsu Memorial Institute of Pathology, Sydney Hospital, N.S.W.--Secretary, Universities' Bureau, 88a Gower Street, London, W.C.1 (January 31).

Assistants to civil and mechanical engineers in the Ordnance Factories, E.D.(F.), Royal Arsenal, Woolwich, S.E.18-The Chief Superintendent.

A male junior assistant chemist at the Royal Gunpowder Factory, Waltham Abbey, Enfield Lock, Middlesex-Principal Clerk.

Temporary assistant civil engineers in the Air Ministry-Secretary (W.B.9), Room 712, Adastral House, Air Ministry, Kingsway, W.C.2, by post-card for form of application.

A male laboratory assistant (Grade II) at the Experimental Station, Porton, near Salisbury, of the War Department-Commandant of the Station. 